\title{
The Legal Responsibility of the Doctor on the Family's Demand to Stop the Treatment of the Terminal Patient that Causes Death
}

\author{
Indar Indar ${ }^{1 *}$, Slamet Sampurno ${ }^{2}$, Samriah Samriah ${ }^{3}$, Alwy Arifin ${ }^{4}$, Anwar Mallongi ${ }^{4}$, Yusri Abadi ${ }^{4}$, Nurhayani Nurhayani ${ }^{4}$ \\ ${ }^{1}$ Professor of Public Health Law, School of Public Health, Hasanuddin University, Makassar, Indonesia; ${ }^{2}$ Professor of Law, \\ Faculty of Law, Hasanuddin University, Makassar, Indonesia; ${ }^{3}$ Lecturers, Faculty of Law, Hasanuddin University, Makassar, \\ Indonesia; ${ }^{4}$ Lecturers, School of Public Health, Hasanuddin University, Makassar, Indonesia
}

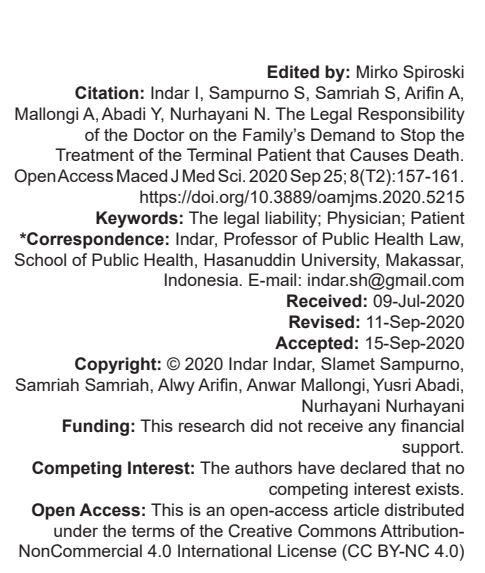

Introduction

Health is important for everyone. In a healthy condition, a person can think and do all his/her activities optimally and productively. Curative efforts need to be supported by good health-care facilities as well as a good medical service system from health-care facilities. Therefore, a person needs another party who has the expertise to cure him from the disease he suffered.

According to the Constitution of the Republic of Indonesia 1945, on article 28H Paragraph 1, it is stated that "every person has the right to get the prosperity physically and mentally, to live and to obtain a good and healthy environment, and to be entitled to health care." Law Number 36/2009 on health has also regulated the right of every person to get good quality, safe, and affordable health services. Hence, the right to live and obtain good health services is an absolute for every citizen.

Physician is a scientist who is educated professionally to provide help to everyone who needs medical services. Medical education has provided knowledge, skill, and professional attitude for their student to be a competent doctor based on professional behavior to provide help to others. As a profession, medical intervention is a risky action. The risk is unpredictable or the risk occurs due to wrong doctor's intervention (the intervention does not conform with the medical profession standard and medical procedures).

In the Article 45 of Law 29/2004 on Medical Practice, the agreement occurs between the health worker and the patient is a form of consent from the patient before the health worker performs the medical action to the patient. Such a high-risk medical intervention must be given by written consent and signed by the person who has the right to give consent. The agreement on informed consent is given so that the patient or the patient's family can better understand the risks that could occur.

Nowadays, the system of the medical services performed by health workers as a curative giver is given priority by the community, however, all positive assessments of the health profession begin to fade because in the healing efforts performed by health professionals, in this case referred to a doctor, has unintended result to the patient or patient's family. There 
are some malpractices conducted by a doctor or nurse in applying science and skills in the health intervention. Such undesirable consequence is an inherent risk of such medical intervention. The agreement between the health worker and the patient is a type of effort and it is not a commitment to the process but merely on the outcome, so the risk of medical action could occur and may result the death of the patient.

The problem of unintended health-care intervention to the patients or patient's family often occurs in the world of health, especially to terminal patient. The terminal condition is a condition where a person has a disease/illness that has no hope of recovery so it is closed the process of death. The condition of the terminal patient is sometimes misunderstood by the family if undesired condition occurs to the patients [1], [2].

In certain condition, the family of the terminal patient often asks the doctor to release the medical aids of life support. The reasons are vary such as the family of the patient wants to bring the patient to the house so that the person could die peacefully at home; another reason is because of the lack of money. However, it is still a dilemma for medical profession since there is still no exact rule on the guidelines on patient's right to reject the provision of life support. The guidelines should provide the outline to protect the right of the patient to determine his desire, to die naturally, as well as to allow doctors and family to make a decision without any fear of legal aspect because it is the right of the patient.

Based on the above problem, this study aims to analyze the legal liability of the doctor at the request of the family to terminate the treatment of the terminal patient that causes death.

\section{Research Method}

\section{Type of Research}

The type of research is normative-empirical approach. The normative approach (law as a norm or das sollen) and the empirical approach (law as social reality, culture, and das sollen). The normative-empirical legal research is legal research on the implementation of normative law (codification, law, or contract) on any particular legal event occurs within a society (Abdul Kadir Muhammad, 2004).

\section{Location}

The research was conducted at the hospital of Bontang City with the consideration that the location is a representative place to identify some cases of terminal patient.

\section{Types and Data Sources}

Types of data used are primary data and secondary data. Primary data are collected directly by doing interviews and observation of the reports in the form of unofficial documents with relevant institutions to be processed by researcher. Secondary data are collected by documentation and other written material related to the object of the research.

\section{Data Collection}

The data are from field research, that is, research conducted directly to the object to be studied. Secondary data are obtained from library, that is, to study scientific papers, rule and regulation, as well as legislation, and other sources related to the material to be discussed by the researcher.

\section{Population and Sample}

The population in this study was all cases of termination of treatment of the patients at Bontang Hospital. The determination of sample was conducted by purposive sampling technique. The purposive sampling is the selection of special cases of termination of treatment of the terminal patients at the request of the family which causes the death of the patient or there was a prediction to be an euthanasia action.

\section{Data Collection Technique}

Data collection techniques used in conducting field research and literature research are (1) interview technique, that is, data collection directly by asking question and reply by the interviewee and (2) documentation technique, that is, data collection technique using documents, and records related to the problem to be discussed.

\section{Data Analysis}

Data analysis technique used is qualitative analysis to describe the result of the data obtained in the research, both primary and secondary data. The data are presented in the form of explanation and description as well as the conclusion to answer the formulation of the problem.

\section{Results}

Table 1 shows the physician who has a duty to monitor the condition of the patient in the ICU/ ICCU room Bontang Hospital. From the above table, there are six medical doctors. All of the doctors have 
a registration certificate (STR) and practice license (SIP) at medical service of ICU/ICCU Bontang Hospital. Medical Practice Law stated that "a physician is required to have STR and SIP as a form of formal legality of his medical practice towards the patient."

Table 1: The description of the physician doctor at the ICU And ICCU Taman Husada Hospital, Bontang City

\begin{tabular}{llll}
\hline NO. & Physician at ICU and ICCU room & STR & SIP \\
\hline 1 & Dr. F & $\checkmark$ & $\checkmark$ \\
2 & Dr. W & $\checkmark$ & $\checkmark$ \\
3 & Dr. E & $\checkmark$ & $\checkmark$ \\
4 & Dr. A & $\checkmark$ & $\checkmark$ \\
5 & Dr. T & $\checkmark$ & $\checkmark$ \\
6 & Dr. Y & $\checkmark$ & $\checkmark$ \\
\hline Data Source: Primary data (Personnel of Bontang Hospital).
\end{tabular}

Table 2 shows that there are 14 physicians in charge of patient at Bontang Hospital. All the doctors also have a registration certificate (STR) and practice license (SIP) to perform medical service at Bontang Hospital. The data from Tables 1 and 2 are important to emphasize because a letter of informed consent will be cancelled if the doctors do not possess STR and SIP.

Table 2: Physicians in charge of patient (DPJP) Taman Husada Bontang Hospital

\begin{tabular}{llll}
\hline No. & Medical Doctor & STR & SIP \\
\hline 1 & Dr. H, SpAn (Room responsible person) & $\checkmark$ & $\checkmark$ \\
2 & Dr. S, SpJP (Sp. Lung) & $\checkmark$ & $\checkmark$ \\
3 & Dr. D, SpPD (sp. Internal disease) & $\checkmark$ & $\checkmark$ \\
4 & Dr. N, SpPD (Sp, Internal disease) & $\checkmark$ & $\checkmark$ \\
5 & Dr. A, SpS (Sp. nerve) & $\checkmark$ & $\checkmark$ \\
6 & Dr. D, SpP (Sp. Lung) & $\checkmark$ & $\checkmark$ \\
7 & Dr. H, SpB (Sp. Surgery) & $\checkmark$ & $\checkmark$ \\
8 & Dr. K, SpB (Sp. Surgery) & $\checkmark$ & $\checkmark$ \\
9 & Dr. N, SpM (Sp. eye) & $\checkmark$ & $\checkmark$ \\
10 & Dr. A, SpKK (Sp. Skin) & $\checkmark$ & $\checkmark$ \\
11 & Dr. G, SpA (Sp. cild) & $\checkmark$ & $\checkmark$ \\
12 & Dr. F, SpOG (Sp. Obstretry dan Ginekology) & $\checkmark$ & $\checkmark$ \\
13 & Dr. C, SpOG (Sp. Obstetri dan Ginekology) & $\checkmark$ & $\checkmark$ \\
14 & Dr. E, SpPK (Sp. Patology Klinik) & $\checkmark$ & $\checkmark$ \\
\hline Data Source: Primary Data (Personnel of Bontang Hospital). & \multicolumn{2}{|c}{}
\end{tabular}

The researcher has explained that to assess the competence of the doctor, they could be identified by a letter of STR and SIP.

Table 3 shows that the number of patients from January 2015 to December 2015 was 304 patients while the number of patients in January 2016-April 2016 was 121 patients. The total number of patients from January 2015 to April 2016 was 426 patients.

Table 3: The number of patient at ICU and ICCU room from January 2015 to April 2016

\begin{tabular}{ll}
\hline Year & Number \\
\hline January 2015 to December 2015 & 304 \\
January 2016 to April 2016 & 121 \\
Total & 426 \\
\hline Data Source: Secondary data (Bontang Hospital). &
\end{tabular}

Table 4 shows that there are three terminal patients who have stopped the treatment or terminate the medical action at the request of the patient's family (at their own request is abbreviated as APS).

Table 4: The number of patient, left the hospital on his own decision at ICU and ICCU room Bontang Hospital

\begin{tabular}{lllll}
\hline No. & Name & Medical record & Age & Diagnose \\
\hline 1 & Ny. H & 13.14. & 67 Year & Encefalophaty hepaticum+stroke non hemoragic \\
2 & Tn. S & 14.85. & 49 Year & Shock Sepsis \\
3 & Ny. M & 14.43. & 67 Year & Tumor Colli \\
4 & Ny. J & 14.85. & 72 Year & Illeus Paralitic+acute renal failure \\
5 & Ny. S & 15.75. & 80 Year & Effusi pleura bilateral, suspect lungs. Mass \\
\hline & Data sources: Patient left the hospital (at the request of the family) at ICU and ICCU Bontang Hospital. \\
Registration of the hospital.
\end{tabular}

The interview with one of the doctors at Bontang Hospital stated that:

Two patients, that is, Mrs. S and Mrs. J had been treated in the ICU and ICCU rooms. However, his family asked for leaving the hospital at the request of the patient's family (APS). Both patients were elderly patients.

Another patient, Mrs. M was treated in the nursing room but due to her consciousness condition, soon she was transferred to ICU. Having been treated in ICU for 3 days and the patient's unconsciousness, the family asked for leaving the hospital (APS) with the reason to bring his mother died in peace at his house. The prognosis was bad because elderly patient.

Mrs. A patient entered the ICU from a clinic, diagnosed with unconsciousness. Having been treated in ICU room for 2 days, his family asked for leaving the hospital (APS) with the reason to bring his mother to spend her rest of life at the house.

\section{Discussion}

This study demonstrated that the responsibility of the doctor on the discontinuation of the treatment of patients at the request of the family on terminal patient that caused death was professional responsibility, among others, the ethical responsibility (referred to objective theory) and the discipline responsibility (referred to mix theory) as well as legal responsibility (criminal) referred to the theory of retaliation.

In a medical practice law, a physician was required to have STR and SIP as a form of formal legality of his medical practice to the patient. If a doctor did not have STR and SIP, the doctor could be punished and the letter of informed consent would be cancelled. The punishment of the doctor who did not have STR and SIP was stated in the medical practice law, that is, put in prison for a maximum of 3 years or a maximum fine of Rp10,000,000,000.

A doctor and other health professionals would be charged for ethical violation if they acted against their professional code of ethics [3]. The ethics code is defined as a set of principles or moral values, which concern the whole principles or the value to decide which one is good or bad. Ethics code for a medical profession is a moral guideline for a doctor to perform their profession, consists of four parts, namely: (1) General obligation; (2) doctor's obligation to patient; (3) doctor's obligations to his colleagues; and (4) doctor's obligation to himself [4].

Medical profession discipline is to obey the rules and regulation on the application of science in the implementation of medical practice. The violation of the medical profession discipline could be found 
in the form of (1) Medical negligence, that is, doing something that should not be done or not doing something what should be done and (2) professional misconduct [5]. In the legal aspect between physician's right/responsibility and patient's right in medical action, the law covered both private law and public law [6]. In addition, the form of legal relationship between the two laws was a consent of medical action (known as informed consent). The agreement between the doctor and the patient was from the Medical Practice Law and Regulation from Health Ministry on the Approval of Medical Intervention [7].

Action against the law as stated in the civil law was determined by:

(a) Actions that violate the current law. (b) Violate the right of others guaranteed by law. (c) Actions that are contrary to the offender's legal obligation, or (d) action that is contrary to the norms, or (E) actions that are contrary to the good attitude in certain society to take into account the interests of other people [8].

There was no intention and/or negligence of the doctor to terminate of the treatment of terminal patients at the request of the family (as in the view of researchers). There was a justification or an excuse for the doctor. This justification was based on the request of the family (sometimes under the force of the family).

In the reality, the victim in the termination of treatment was actually the patient and further the nearest patient's family. However, it became a problem when the termination of the treatment was requested by his or her family (as in the view of the researcher).

In the case of the termination of treatment, there was no causal relationship between the action of physicians who were forced to stop the treatment at the request of the patient's family with the loss. If we analyze, the termination of the treatment that caused death to terminal patients, then there was no unlawful intervention conducted by the doctor. (as in the view of the researcher).

To determine whether a doctor had committed unlawful intervention as stated in the criminal law, then there were some requirements. The requirements were divided into two, namely, (1) action (actus reus) consisting of matching the formulation of the sue, against the law, there was no good excuse and (2) criminal responsibility (mens rea) consisting of, that is, level of responsibility, there were some mistakes (dolus or culpa), there was no excuse for forgiveness [9].

In criminal law, the termination of treatment caused in death can be considered as murder, fulfilling the formulation of Article 338 of the Criminal Code or even as panned murder as referred to Article 340 of the Criminal Code, Article 334 of the Criminal Code, namely, the murder of a victim's request, and Article 345 of the Criminal Code concerning assisting a person suicide. Termination of treatment resulting in death can also be attributed to Article 304 of the Criminal Code in the case of omission and Article 531 of the Criminal Code.

The theory of retaliation justified punishment because a person had committed a violation. To the doer, there must be a punishment. No question of the consequences of punishment for the convicted person was raised. The material for judgment was only the past, that is, the time the criminal was conducted whereas the future of the convicted person had never been questioned [10], [11], [12].

In relation to physician's responsibility, the retaliation theory belongs to the doctor's responsibility in the field of law. It must be taken into account that in the case of the doctor's responsibility, there were several punishments, as in criminal law, ranging from death punishment, imprisonment, paid the fine, etc. [13]. The emphasized from the theory of retaliation was the responsibility of law for a doctor not to do the same action.

Objective theory justified punishment because the theory was based on the purpose of punishment, that is, for the protection of the community or the prevention of the criminal action. The difference of some theories was actually on the way to achieve the objectives as well as the use of the prevention of criminal action. The punishment and the imprisonment were intended to provide a lesson for a doctor on the importance of a cautious principle in providing medical treatment. The doctor must follow the SOP that guided the physician to do the intervention. In this case, the researcher classifies it to ethical accountability.

The mistakes conducted by a physician not only take into account the past (as found in the theory of retaliation) but also take into consideration the future (as stated in the objective theory). Therefore, the punishment will give a sense of satisfaction for MKEK, MKDKI, to the doctor and to the community. The researcher's analyzed that the combined theory was the responsibility of the professional discipline [14].

\section{Conclusion and Recommendation}

Based on the result and discussion, it can be concluded that the responsibility of the doctor on the termination of the treatment of patients at the request of the family on terminal patient that caused death was professional responsibility, among others, the ethical responsibility (referred to objective theory) and the discipline responsibility (referred to mix theory) as well as legal responsibility (criminal) referred to the theory of retaliation. MKEK and MKDKI are those who hold the responsibility of the physician profession. Whereas in the legal aspect, the judge will have the responsibility to examine, to decide, and to prosecute the verdict 
in the court. As the judge was the employee under the Supreme Court. Regarding the termination of the treatment of patients at the request of the family on terminal patient that caused death, the legislator should make a new law as a legal protection for both patients and doctors. The new law should accommodate and provide solution between doctor's responsibility and patient's rights in medical intervention.

\section{References}

1. Indar. Konsep dan Perspektif Etika dan Hukum Kesehatan Masyarakat. Yogyakarta: Pustaka Pelajar; 2014.

2. Indar. Dimensi Etik dan Hukum Keperawatan. Makassar Masagena Press; 2014.

3. Nasution BJ. Hukum Kesehatan Pertanggung Jawaban Dokter. Jakarta: Rineka; 2005.

4. Achadiat CM. Dinamika Etika dan Hukum Kedokteran Dalam Tantangan Zaman. Jakarta: EGC; 2006.
5. Sadi MI. Etika dan Hukum Kesehatan Teori dan Aplikasinya di Indonesia. Jakarta: Prenada Media Group; 2015

6. Notoatmodjo S. Etika and Hukum Kesehatan. Jakarta: Rineka Cipta; 2010.

7. Siswati S. Etika dan Hukum Kesehatan dalam Perspektif Undang-undang Kesehatan. Jakarta: Rajawali Pers; 2013. https://doi.org/10.35706/positum.v3i1.2663

8. Fuady M. Perbuatan Melawan Hukum. Bandung: Citra Aditya Bakri; 2013.

9. Ohoiwutun YA. Bunga Rampai Hukum Kedoteran. Malang: BayuMedia Publishing; 2007.

10. Sutarno H. Hukum Kesehatan Eutanasia, Keadilan dan Hukum Positif di Indonesia. Malang: Setara Press; 2014.

11. Republik Indonesia. Undang-undang Dasar Negara. Indonesia: Republik Indonesia Tahun; 1945. https://doi.org/10.37035/ajh. v14i1.1427

12. Tentang Praktik Kedokteran. Undang-undang Nomor 29 Tahun 2004. Indonesia: Tentang Praktik Kedokteran; 2004. https://doi. org/10.25157/jigj.v6i1.1245

13. Tentang Kesehatan. Undang-undang Nomor 36 Tahun 2009 Indonesia: Tentang Kesehatan; 2009. https://doi.org/10.31219/ osf.io/8e6an

14. Indar. Etika dan Hukum Kesehatan. Makassar: Lembaga Penerbitan Universitas Hasanuddin; 2010. 